\title{
The Impact of the Economic Recession on Canadian Interuniversity Sport (CIS) Programs
}

\author{
Todd Aughey, Karen Danylchuk, and Katie Lebel \\ The University of Western Ontario
}

\begin{abstract}
There is a paucity of research that addresses the impact of the recent economic recession on Intercollegiate Athletics programs in Canada. This study investigated the impact of the recession as it relates to Canadian Interuniversity Sport (CIS), the national governing body for university sport in Canada. Telephone interviews were conducted with the Director of Athletics at eight universities across the country, as well as the Chief Executive Officer (CEO) of the CIS. Results of the study indicated that very few schools had been asked to make dramatic reductions to programming. Athletic programs have proceeded cautiously with budget spending, suspicious that the worst may not be over. The greatest financial impacts were experienced in general University as well as athletic-specific endowments.
\end{abstract}

In the wake of the recent economic recession, the reaction of the sporting world has garnered much interest. In the past, sport seemed to find itself largely immune to the effects of economic crisis. In the current business cycle, the bleak financial landscape revealed vulnerabilities within many sport structures. The mainstream professional sports of basketball (Lombardo, 2009), football (Mickle, Fisher, Ourand, Lefton, \& Kinmartin, 2008a; Mickle, Fisher, Ourand, Lefton, \& Kinmartin, 2008b), and ice hockey (Fisher, 2008) all reported ticket discounting strategies occurring in markets that normally do not need to worry about empty facilities. Reductions in corporate sponsorship have wreaked havoc on budgets that had come to rely heavily on this outlet as a major revenue stream. Professional sports have also witnessed mergers, team bankruptcies, athlete payroll purging, administrative staff reductions, and in some extreme situations, league cancellations (Ellington, 2008). The common sports fan has been forced to become more selective in what they attend and what they purchase. As disposable income is exercised with greater discretion, fewer people are prepared to travel long distances to support their team.

University and college sports have also been forced to grapple with dramatic changes as a result of the changing financial climate (Hogshead-Makar, 2010; Lapchick, 2010; Perko \& Hesel, 2010; Toma, 2010; Zimbalist, 2010). Teams have been cut. Dismal stock market performances have had severe impact on endowments. Budget crunches have forced early retirement packages and lay-offs, and

Aughey, Danylchuk, and Lebel are with the School of Kinesiology, The University of Western Ontario, London, Ontario, Canada. 
decreases in corporate/alumni giving (Denhart, Villwock, \& Vedder, 2009). In the United States (U.S.), the collegiate sport enterprise has witnessed a number of daunting challenges. Fewer schools are fielding varsity programs and many have reduced scholarship funding. Athletic programs now travel shorter distances for competition and field fewer athletes. Major student-athlete service restrictions have been enforced on what was once known as an "industry standard." Although some of the highly competitive programs have felt the recession to a lesser degree, most varsity programs have been forced to reconsider build projects, have received less in sponsorship and alumni dollars, and have had to work much harder to maintain attendance numbers (Coyne, 2009; Perko \& Hesel, 2010; Zimbalist, 2010).

University Senior Administrators on both sides of the border have struggled over the past two years to balance the budget, primarily because of under-performing institutional endowments and limited flexibility relative to personnel (Glenn \& Schmidt, 2010; Zimbalist, 2010). Many postsecondary institutions typically use the stock market gains of their endowments to support operations. With so many schools losing money on these endowments between 2007 and 2010, and because so many campus faculties and departments seemed to "get by" on limited budgets year after year, Senior Administrators have had very little maneuverability in their budget proceedings to bring about reasonable solutions (Perko \& Hesel, 2010; Schlabach, 2009). Exclusive of negotiating new contract terms with the various unions on campus to reduce costs and ultimately eliminate jobs, the University in many instances has been forced to institute unilateral cuts, hiring freezes, and tuition increases.

Within the Canadian University environment, interuniversity sport programs have not been invulnerable to the effects of the economic recession. Though the Canadian economy did not suffer to the same degree as the U.S. market, a serious financial strain was felt across the country. The purpose of the current research was to examine the impact of the recent economic downturn on intercollegiate sport operations at various Canadian universities. The goal of the study was to uncover specific strategies that Athletic Directors have employed to increase their departmental revenues while stabilizing spending. It was anticipated that the "currency crunch" tactics that Athletic Directors have instituted to offset the financial challenges paralyzing the postsecondary environment could be transferable to most Intercollegiate Athletics programs across the country. It was also predicted that some of the findings in this Canadian study would be transferable to U.S. collegiate sports administrations. Three research questions guided the current study:

1. Has the economic recession affected Canadian interuniversity athletics programs, and if so, how?

2. What is being done to address the situation?

3. Has the recession had any effect on how the programs are funded or how they might be funded in the future?

\section{Canadian Intercollegiate Sport Landscape}

Canadian Interuniversity Sport (CIS) is the national governing body for men's and women's university sport in Canada. The CIS is the highest competitive level of 
university sport in the country and is composed of the majority of degree-granting academic institutions in Canada. There are currently 52 CIS member institutions with over 10,000 student-athletes and 550 coaches from four geographically distinct regional associations: Canada West Universities Athletic Association, Ontario University Athletics, Quebec Student Sports Federation, and Atlantic University Sport (CIS, 2010).

Similar to its U.S. counterpart, the National Collegiate Athletic Association (NCAA), the CIS provides high performance competitive opportunities for student athletes within the philosophical framework of an educational environment (Danylchuk \& MacLean, 2001). The CIS features 21 national championships in 12 different sports and provides international opportunities for Canadian student-athletes at Winter and Summer Universiades, and 32 World University Championships.

Canadian Intercollegiate Athletic departments may be housed within an academic unit (e.g., physical education/human kinetics/kinesiology), or exist as their own unique and autonomous unit, depending on the organizational structure of each campus. Some intercollegiate programs are funded strictly through student ancillary fees, whereas others rely on support directly from the University's central budget. Danylchuk and MacLean (2001) further noted the spectrum of variability between institutions' facilities, operating budgets, and sport offerings.

One of the defining characteristics of the CIS relates to its funding opportunities for student-athletes in the form of athletic financial awards (i.e., athletic scholarships, leadership awards, merit awards, and needs-based grants). CIS regulations state that the maximum amount a student-athlete may receive annually includes tuition and compulsory fees for the academic year. However, as athletic scholarships are the responsibility of each university and also subject to regulations from each of the four regional associations, the number and value of scholarships varies widely from one university to another across the country (e.g., maximum $\$ 3,500$ in the Ontario conference; O'Reilly \& Seguin, 2009). Aside from the funding amount, CIS regulations require first-year student-athletes to have a minimum $80 \%$ entering average. This financial scheme stands in stark contrast to the athletic scholarships available in the U.S., the likes of which can absorb the costs of tuition, housing, books, and travel. In 2008-09, Canadian universities provided a combined $\$ 9,997,758$ in athletic scholarship money to $22 \%$ of CIS student-athletes. The average dollar value of each award was $\$ 2,518$. The largest scholarships for men's sport were provided in basketball, hockey, and football. For women, the sports of basketball, volleyball, and hockey received the largest financial awards (CIS Communications, 2010).

Although the smaller number and size of athletic scholarships in Canada has resulted in a number of talented Canadian athletes choosing to attend college or university in the U.S., recent regulations have begun to reflect the desire of Canadian institutions to keep the best athletes in Canada by increasing the maximum award amounts. These changes have in turn allowed Canadian universities to compete on a more level playing field with smaller American universities. A few CIS universities even compete in a limited number of sports in leagues south of the border, such as the National Association of Intercollegiate Athletics (NAIA) or Division II of the NCAA.

Contrary to U.S. counterparts, Canadian Intercollegiate Athletics are far from big business. There are no multimillion dollar television contracts; in fact, few 
university events even appear on television. Those events that do garner coverage typically do so without much advanced hype or fanfare and tend to draw low ratings. Danylchuk and MacLean (2001) surmised that the drastically different funding situation Canadian Intercollegiate Athletics are faced with leaves the role of varsity sport on Canadian campuses "parochial in nature" (p. 374). They suggested the Canadian model exemplifies pure amateur athletics that are participant focused and nonprofit oriented.

\section{Impact of the Recession on Canadian Intercollegiate Sport}

The current economic uncertainty has forced considerable change within the Intercollegiate Athletics landscape. A strong retrenching of athletics programs has been documented in the U.S. as Athletic Directors scramble to adapt to the changing times (see Perko \& Hesel, 2010; Zimbalist, 2010). Many schools in Canada through 2009 reported financial unsteadiness, which required immediate campus-wide cost-cutting measures to be implemented. The majority of the documented challenges involved mounting operating expenses, a demand to reduce and/or freeze all campus salaries, urgency to cut course offerings and degree programs, dismal investment returns, and much more frequent communiqués from Presidents' offices (Cade, 2010; Campbell, 2010; Casey, 2010; Cummings, 2010; Dunville, 2010).

Specific literature linking the Canadian economy with Intercollegiate Athletics is minimal. Lajoie (2009) reported that the University of Windsor in South-western Ontario was facing a \$5M shortfall for the 2009 fiscal year, and that they might be forced to trim four varsity sports from their offerings. They considered this sport elimination option to contribute to the University's mandate of all campus departments playing a part in the cost saving diet. Matchett (2009) detailed a similar circumstance at the University of Calgary: too many programs and too little funding. The Calgary Dinos Athletics Department purportedly shifted resources and restructured operations through the summer of 2009 to focus on eight core team sports and four core individual sports. It was expected that this strategy would ensure the long-term competitiveness of all the Dinos teams.

Given the limited scholarly research on the impact of the economic recession upon Canadian Intercollegiate sport, it was deemed an investigation was indeed warranted. This study, therefore, contributes to a recognized void in the literature through the provision of recession strategies using a Canadian gaze.

\section{Method}

\section{Research Method}

This investigation employed a qualitative methodology. Telephone interviews were conducted with the key stakeholders for Intercollegiate Athletics-the Athletic Directors (AD)-at eight universities across Canada. Two AD's were randomly selected from each of the four regional CIS conferences based on school enrolment numbers. One University was selected from each conference with an enrolment 
greater than 15,000 students, while one was selected with an enrolment of fewer than 15,000 students in an effort to provide a balanced viewpoint from both large and small institutions. It was believed that the more populated a school, the higher the probability that the athletics program would be more comprehensive.

A supplemental interview with the CIS CEO was also conducted. Price (1972) suggested that the CEO is an important constituent to contact because of his/her position of authority within the organization and his/her involvement in funding allocation decisions. In this investigation, it was believed that the CIS CEO would provide a "big picture" financial perspective on all University sport in Canada, in addition to the strategies required by the conference and national association to navigate through the tough financial times.

Three primary research questions guided the interviews: a) had the recession in fact impacted the athletic programming at the Athletic Director's school? b) how had the athletic department managed any financial challenges? and c) what effect had the recession had on both current and future programming?

\section{Procedure}

Interviews were conducted from the researcher's home on a portable telephone device with built-in audio speaker capability. Interviews were recorded electronically to a laptop computer using Microsoft Windows Sound Recorder software. Interviews ranged in duration from 19 to $47 \mathrm{~min}$. Each session was transcribed verbatim and redistributed to the Athletic Director for validation. Once confirmation was received, data analysis ensued.

\section{Data Analysis}

Data were scrutinized for common themes through the process of constant comparative analysis and data codification (Kvale, 1996; Merriam 1998). Where possible, quantitative form was presented to reinforce specific schemes instituted at different campuses to combat current economic issues. Key points were captured, steering questions evolved into relevant categories, and a number of administrative cost-saving solutions emerged.

\section{Findings}

\section{Effect of Recession on Intercollegiate Athletics}

The majority of Athletic Directors reported that they believed their University's current financial picture was in a more precarious position than their own Athletic Department. Only one school reported a major impact from the economic downturn, with two schools describing some impact and five schools claiming no direct effects. Major effects were experienced in the form of a forced cutback of varsity teams from the sport program. It was reported that many of this particular school's challenges were correlated with the adverse influence of major industries in their community. They were faced with significant dropoff rates in ticket sales and advertising revenue, which had a considerable impact on both their operating budget and fundraising potential. The school was also 
faced with a combined 13-percent cut to its operational funding from the Central University Administration.

Of the schools indicating moderate recession impact, the common sentiment was that the recession had not affected their programs as much as they had anticipated. These schools were wary of the future though and expressed concern about the long-term effects of the financial turmoil within the larger University setting. Among the schools indicating no direct effects from the economic turndown, no changes in funding were reported for the current fiscal year. No adjustments were made to the teams or sports that the University offered and existing budgets were maintained. The fact that the downward spiral of the economy took root after the 2009 budget approval process was, however, highlighted and held accountable for this limited influence. Most participants worried that the true impact of the recession remained to be seen on their campus. A strong argument for fiscal restraint over the next 12 months was made as Athletic Directors spoke to their heightened caution in spending. It was hypothesized that the true measure of economic turmoil would be seen over the next two years. The situation was likened in some cases to the on-campus calm before the eventual and inevitable storm. As budgets are cut, external revenue sources are drying up and operational expenses are mounting. Although it was agreed that the economic situation in most cases was not as foreboding as originally anticipated, all schools indicated concern surrounding upcoming decisions and recognized that this was not a period of growth for the CIS, their respective conferences, and most importantly, their individual campuses.

Four schools believed that the financial crisis was the impetus behind their current Athletic Department reviews. These schools all stated that this process has been and will continue to be a positive influence on their programming. All schools felt that the review forced them to look at themselves critically and develop better ways of accomplishing their goals, from both a revenue and expense perspective. It brought about comprehensive discussion on what needed to be done to remain competitive in respective conferences and on the national stage. It was recommended that regular audits of expenditures be conducted within each department, forcing Athletic Departments to become more efficient.

The most significant concern raised by all participants was the effect of the recession on University endowment funds earmarked for scholarships and bursaries. Diminished returns and mounting losses in this significant source of funding leave Universities with few options and very difficult decisions to meet necessary budget projections.

Universities count a lot on their endowments, right? For operating money. So when the rate of return on your endowments is down, that means you've got a lot less operating money on an annual basis, and you've got to pull back. So much of the University dollars are tied up in salaries, then that's not easy for Universities to make change all of a sudden, when your endowments are down. So it's a ripple effect. It affects all of the departments. (P7)

Academic subsidy to athletes was also viewed as a major contributing factor to athletic success. The reduction in this funding opportunity negatively affects student-athlete recruitment success via an inability to provide financial incentives. 
Findings additionally indicated a slight to moderate reduction in both corporate and alumni giving, a further barrier impacting scholarship capabilities.

\section{Measures to Address the Recession}

Perhaps ironically, the financial crisis was seen by some participants as an opportunity in disguise. Choosing to view the situation in a positive light, Athletic Directors indicated that the predicament had forced them to focus on what their real priorities were as a school. The dire economic climate served as a catalyst to perform a serious review of all Athletic programming.

I'll say that the economy is sometimes the engine that drives the decisionmaking process that just gets us on with the things that we should be doing anyway. It seems like the economy today is somewhat turning around, but I think we need to make these decisions anyway at many institutions. We've been growing for the last ten or fifteen years and sometimes avoiding making decisions. So in a way, I accept the challenge of it, and say that we'll be better off coming out the other side. (P5)

One school used the strained financial picture to springboard discussions with their staff and coaches about the need for team-by-team financial management and better season planning and recruitment practices. It was documented that this helped with staff morale, and afforded the varsity administration an opportunity to keep everyone on the same page by improving communication strategies.

Another school created a new contract sponsorship coordinator position, and some marketing positions were converted into Business Manager-type positions focused on developing corporate / alumni relationships on a more consistent basis. A somewhat surprising revelation was discovered as half of the schools polled credited the recession for its role in cultivating alumni donations, a previously untapped revenue stream. With proper organization, schools were realizing the potential of alumni giving as a lucrative revenue source.

All schools reported a commitment to becoming more self-sufficient through the downturn, so as to limit their reliance on the University to maintain their sport offerings. Most were starting "at home" by paying greater attention to their presence on campus and recognizing that campus visibility would pay dividends down the road. One school partnered with their Public Relations department to reach out to more students, staff, and faculty by offering game discounts and participating in an online / poster marketing campaign. Another school invested a considerable amount of discretionary funding on campus marketing efforts to try to get more "butts in the seats," believing this strategy would ultimately trickle down to all other aspects of their operations.

Three schools indicated that increasing revenues would have to be their focus going forward, because trimming expenses just did not seem to be possible without the elimination of sports. Considering that community advertising and sponsorship opportunities had essentially dried up, these schools expressed that they had to change their focus and become more creative. All Athletic Directors conveyed fiscal conservatism and cautious decision-making toward how dollars were being allocated and spent by their teams and their respective administrations. 


\section{Effect on Program Funding}

There were many similarities between institutions regarding budgeting for varsity sport. The majority of respondents reported that their budgets were directly linked to student ancillary fees-in other words, student Athletic and Recreation fees. In many ways, Athletic Directors were grateful that most of their money came directly from the student body, as often times, they believed students were willing to pay this premium out of pride for their institution.

At the majority of schools, the Department of Athletics was imbedded in a specific faculty, often times associated with the Kinesiology Department. These academic units are known as integrated faculties, offering academic classes, facility operations, and student services. The Athletic Directors working in these types of "academic" environments commented that this was a positive position for their program to be in because it provided more budgetary security, while fostering positive research partnerships with faculty members.

All Directors in the study conveyed optimism about the future, though they noted the economy and the financial picture for the entire University was the focal point on their radar. For the most part, participants reflected that the economic crash had not been as big of an issue as they imagined six months previously, but none of them were letting their guard down. They were still concerned and operating very cautiously.

Reasonable student ancillary fee increases would not keep up with inflating costs, and this would lead to Athletic Directors having to render difficult sport choices. Coaches and varsity administrators were already being asked to do too much through their regular workweek, by way of fundraising, organizing special events, and dealing with extra responsibilities that in the past were handled by someone else. Good and loyal employees would begin to choose other professions and alternative employment. It was a very challenging time, but for most of the Directors, a natural and necessary step toward a new reality.

\section{Chief Executive Officer-CIS}

The CIS CEO believed that the University's endowments, including those earmarked specifically for Athletics, comprised the greatest revenue concern for campuses across the country. In line with feedback from Athletic Directors, she believed that most varsity programs were functioning very cautiously and looking for creative ways to operate more efficiently. She noted that, "most if not all universities are tightening their belts and giving their budget a haircut... There is an expectation that groups need to be getting mileage out of every dollar spent and really doing that serious review of budgets". She highlighted the competing priorities between coaches, their athletic administrators, and conference leagues, but astutely stated, "that's what leadership in management is all about today-balancing competing priorities and trying to navigate in the most appropriate way through challenging times".

With regard to sponsorship, the CEO echoed the opinions of many of the Athletic Directors. The CIS was also looking for collaborative opportunities through the crisis. Revealing that $25-30 \%$ of CIS revenues came from sponsorships, the challenges of maintaining sponsor relations were cited. Many contracts were being renegotiated. Some companies had been forced to scale back their sport given their own financial challenges. All companies were now requiring greater value from 
their sponsorship agreements. The CEO stressed the importance of comprehensive sponsorship deals in the pursuit of this avenue of support, envisioning more strategic and creative approaches going forward.

\section{Discussion}

This Canadian study uncovered many similarities to the U.S. literature on the impact of the recession on Intercollegiate Athletics. Considering the numerous parallels between the two sporting associations, CIS and NCAA, this observation is not surprising. Generally, the time period was one of fiscal restraint, self-reflection, and creativity. Fiscal restraint because schools on both sides of the border were required by their Universities to control spending, and in many instances, somehow continue regular operations using a reduced budget. Self-reflection because all departments were obligated to perform program reviews, both on a team-by-team basis as well as within the administration, to determine possible areas of savings and economies of scale. Finally, Athletic Departments were expected to use creativity in the pursuit of new revenue streams: partnerships with organizations both on and off-campus, alumni-giving, different investment strategies, spectator experiences, and special event fundraisers.

Fort (2010) offers a historical review of the sustainability of FBS athletic departments as they relate to business cycles. An appendix to Fort's research highlights a series of management responses from FBS Athletic Directors gleaned from UltimateSportsInsider.com. The numerous cost-saving strategies listed in this dialogue are reflected in the findings of our Canadian study. Athletic Directors in both studies revealed tactics that tended to focus on the dilemma of inflated travel costs. A small, but certainly not exhaustive list of examples include: (a) developing partnerships with airline and ground transportation companies, (b) having teams compete in nonconference exhibitions closer to home, (c) having same-sport teams travel together on road trips, (d) freezing athlete and staff per diems, (e) modifying travel itineraries to save on hotel charges, and (f) reducing the teams' travel complement for road games.

Athletic Directors reported in the current study that they believed their programs were probably in a better financial position than most of their Universities. Plunging endowment funds, skyrocketing costs, and inflexible budgets, due to the significance of personnel salaries within the budget, were all contributors to a very unstable financial picture for Senior Administrators. This caused most cash-strapped schools to take drastic action through the latter stages of the downturn: asking all departments on campus to face unilateral cuts, reductions in course offerings, tuition hikes, staff and faculty lay-offs, and hours of operation reductions in specified buildings on campus.

\section{Conclusion}

This research has revealed that the majority of schools witnessed some kind of impact from the recent recession; however, the degree of the impact was far ranging. While some Universities were forced to cull sport offerings to balance the books, other schools indicated far fewer anxieties such as basic reductions in corporate 
sponsorship support and diminished endowment returns. For the most part, these latter schools reported being able to maintain the status quo within team budgets and athlete services.

The more important conclusion relating to the impact of the economic downturn was the fact that every Athletic Director interviewed seemed cognizant of how difficult the environment was for all industries, including the faculty/staff at each respective Director's University. There was a strong belief that the true wrath of the financial turmoil of 2008-09 would not be fully embraced or understood for two years due to the funding limitations of the University as a whole.

Many programs indicated concern for the stability of future funding. Fostering quality relationships with the student body at each school seemed to be paramount for the Athletic Directors. Similarly, it was conveyed by a number of participants that of utmost importance to a successful varsity sport program was an engaged and supportive Senior Administration. This meant spending the necessary public relations and boardroom time nurturing a constructive rapport with this group of individuals. A final point worthy of mention was the stated importance of new revenue streams to the Athletics operation, even in the difficult economy. With each new sponsor, investment strategy, alumni donation, tournament hosting, raffle or fundraising event, the profile of the department was raised, and elite on-campus sport was one step closer to self-sufficiency.

\section{References}

Cade, B. (2010). President's letter - budget update and salary discussions. The Notice Board. Retrieved from http://www.uleth.ca/notice/display.html?b=300\&s=13414

Campbell, C. (2010, February 25). McMaster University deficit could result in layoffs. Stoney Creek News. Retrieved from http://www.stoneycreeknews.com/ news/article/203642

Canadian Interuniversity Sport. (2010). Athletes' Guide. Retrieved from http://english.cissic.ca/information/student-athlete_info/athletes_guide

Communications, C.I.S. (2010). Awards Statistics. Retrieved from http://english.cis-sic. ca/information/members_infor/pdfs/pdr_research_and_stats/SportRanking_-_english_08-09.pdf

Casey, J. (2010, February 7). Universities face another challenging budget year. Laurier University Public Affairs. Retrieved from http://www.wlu.ca/news_detail.php?

grp_id=0\&nws_id=6126

Coyne, T. (2009, July 13). Colleges doing everything from eliminating sports, cutting scholarships to save money. Associated Press. Retrieved from http://www.washingtonexaminer. com/sports/ap/50654177.html

Cummings, D. (2010, February 10). U of M feeling pinched. Winnipeg Free Press. Retrieved from http://www.winnipegfreepress.com/opinion/editorials/u-of-m-feelingpinched-83868832.html

Danylchuk, K. \& MacLean, J. (2001). Intercollegiate athletics in Canadian universities: Perspectives on the future. Journal of Sport Management, 15(4), 364-379.

Denhart, M., Villwock, R., \& Vedder, R. (2009, April 21). The academics athletics trade-off. Universities and intercollegiate athletics. Center for College Affordability and Productivity. Retrieved from http://www.centerforcollegeaffordability.org/uploads/athletics.pdf

Dunville, J. (2010, March 14). UNB Fredericton facing layoffs. Times \& Transcript. Retrieved from http://timestranscript.canadaeast.com/search/article/980635

Ellington, R. (2008). Feeling the crunch - AFL struggling to survive amid recession. Street and Smith's SportsBusiness. Daily, 15(61), 1. 
Fisher, E. (2008). Can sports weather the storm? Street and Smith's SportsBusiness Journal, 10(46), 1-2.

Fort, R. (2010). An economic look at the sustainability of FBS athletic departments. Journal of Intercollegiate Sport, 3(1), 3-21.

Glenn, D., \& Schmidt, P. (2010, March 28). Disappearing disciplines: degree programs fight for their lives. The Chronicle. Retrieved from http://chronicle.com/article/ DisappearingDisciplines-/64850/?sid=at\&utm_source=at\&utm_medium=en

Hogshead-Makar, N. (2010). Attitudes, latitudes and the collegiate sports arms race:

Unsustainable spending and its consequences for Olympic and women's sports. Journal of Intercollegiate Sport, 3(1), 69-80.

Kvale, S. (1996). Interviews: An introduction to qualitative research questioning. Thousand Oaks, CA: Sage Publications.

Lajoie, D. (2009, February 26). Varsity programs in jeopardy in $\mathrm{U}$ of $\mathrm{W}$ budget crisis. The Windsor Star. Retrieved from http://www.windsorstar.com/Sports /Varsity+programs +jeopardy+budget+crisis/1329303/story.html

Lapchick, R. (2010). The effect of the economic downturn on college athletes and

athletic departments on issues of diversity and inclusion. Journal of Intercollegiate Sport, $3(1), 81-95$.

Lombardo, J. (2009). NBA teams step up ticket discounting. Street and Smith's SportsBusiness Journal, 11(35), 1.

Matchett, B. (2009, April 15). UC Dinos announce programming changes. University of Calgary Sports Information. Retrieved from http://www.godinos.com/news /2009/4/15/ FH_0415091702.aspx?path=fhockey

Merriam, S. (1998). Qualitative research and case study applications in education. San Francisco: Jossey-Bass Publishers.

Mickle, T., Fisher, E., Ourand, J., Lefton, T., \& Kinmartin, P. (2008a). Sacked for a loss: NFL to fall at least \$50M short of revenue goal. Street and Smith's SportsBusiness Daily, 15(58), 15.

Mickle, T., Fisher, E., Ourand, J., Lefton, T., \& Kinmartin, P. (2008b). NFL the latest hit by economy as it plans to cut 150 employees. Street and Smith's SportsBusiness Daily, 15(59), 4.

O'Reilly, N., \& Seguin, B. (2009). Sport marketing: A Canadian perspective. Toronto, ON: Nelson.

Perko, A., \& Hesel, R. (2010). A sustainable model? University presidents assess the costs and financing of intercollegiate athletics. Journal of Intercollegiate Sport, 3(1), 32-50.

Price, J. (1972). The study of organizational effectiveness: The Sociological Quarterly, 13, 3-15.

Schlabach, M. (2009, July 13). Programs struggle to balance budget. ESPN. Retrieved from http://sports.espn.go.com/ncaa/columns/story?columnist =schlabach_ mark\&id=4314195

Toma., J.D. (2010). Intercollegiate athletics, institutional aspirations, and why

Legitimacy is more compelling than sustainability. Journal of Intercollegiate Sport, 3(1), 51-68.

Zimbalist, A. (2010). Dollar dilemmas during the downturn: A financial crossroads for college sports. Journal of Intercollegiate Sport, 3(1), 111-124. 